\title{
A Case Study of Curriculum Implementation and K-13 Challenges in Indonesia
}

\author{
Yeni Nuraeni ${ }^{1, a^{*}}$, Zulela MS $1, \mathrm{~b}$, and Endry Boeriswati ${ }^{1, \mathrm{c}}$ \\ ${ }^{1}$ Post Graduate Elementary Education, Universitas Negeri jakarta, Jakarta Timur, 13220, Indonesia \\ a yeniyayang1973@gmail.com; ${ }^{b}$ zulela@unj.ac.id; c endry.boeriswati@unj.ac.id \\ ${ }^{*}$ Corresponding Author \\ Whatsapp number [+6281298257484]
}

How to Cite : Nuraeni, Y., Zulela, Z., Boeriswati, E. (2020). A Case Study of Curriculum Implementation and K-13 Challenges in Indonesia. International Journal for Educational and Vocational Studies, 2 (1), 14-18. DOI: https://doi.org/10.29103/ijevs.v2i1.2263

\section{ARTICLE HISTORY}

Received:10 October 2019

Revised: 28 December 2019

Accepted: 17 January 2020

\section{KEYWORDS}

Elementary School; Curriculum K-13; Indnesia Education Policy;

\begin{abstract}
The K-13 curriculum has been implemented since July 2013 in several Indonesian schools and might have been in effect in all school arround 2014. The study was aimed to obtain information regarding teachers' difficulties in impelemnting the curriculum 2013. The research was descriptive explorative research by means of qualitative data gathering which conducted from July 2016 to January 2018. The data on teachers' difficulties in implementing the curriculum 2013 were gathered by means of interviews, observation, and focus discussion with elementary school teachers and the vice principals of curriculum in Tangerang City Indonesia. The result of the study showed that in implementing the curriculum 2013 , the teachers had more difficulties the content standard $35.2 \%$, the process standard $25.3 \%$, the assessment standar $20.0 \%$, The teacher and educational personal standar $4.2 \%$, the infrastructure standard $4.2 \%$, the management standard $4.2 \%$, the graduate compotence standard $3.90 \%$, and the funding standard $3.0 \%$. The highest of them is the difficulty in understanding the implementation standard, the second on processes standards and third on assessment standards. This reseacrh is expected to lead to an outcome that will answer the needs of the community that the curriculum 2013 requires a lot of improvements and development so that all the problems found can be solved.
\end{abstract}

This is an open access article under the CC-BY-SA license.

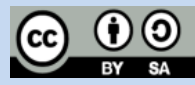

\section{INTRODUCTION}

Starting in the 2013-2014 academic year there were formal schools which consists of the elementary level, junior high school, senior high school in Indonesia begun to implement curriculum 2013 (K-13). Before July 2013, the educational system in Indonesia used curriculum prepared at the school level was implemented since July 2006. It was developed by each school, in accordance with the conditions of the school, regional characteristics, social culture characteristics. Related to the implementation of this curriculum, the school has full authority and responsibility to develop strategies and set priorities in education. The keywords of this curriculum are the local wisdom, selfdevelopment activities, mastery learning and life skills.(Retnawati, Hadi, \& Nugraha, 2016).
Curriculum 2013 was implemented in the grade of 1.2, 4 and 5 (for elementary school), grade of 7, 8, (for junior high school) and grade of 10 and 11 (for senior high school). The K-13 curriculum was developed in on the theory of "education based on the standard" (standard-based education), and the theory of competency based curriculum. Competency-based learning is an approach to education that focuses on the student's demonstration of desired learning outcomes as central to the learning process In general, Curriculum 2013 contains four elements of change. They are (1) standard of graduate competencies, (2) standard of contents, (3) standard of learning processes, and (4) standard of assessment (Prihantoro, 2014). 
Curriculum 2013 covers attitudes, cognitive and skills to develop individual learners in religion, art, creativity, values, communication, and the various dimensions of intelligence that suits the learner and the needs of the community, nation and mankind.(Kemendikbud RI, 2014). On other hand, there are four major U.S. curricular initiatives that can be identified in the history of curriculum development and reform: (1) academic rationalism, (2) the social effi- ciency model, (3) progressive education, and 4) social reconstructionism (Family \& Surveys, 1861).

the importance of students taking an active role in their own educational process, and they support this assumption of best practice with an extensive literature review. They begin by providing a rationale for students sharing responsibility of learning with their teachers. They then present three types of non-curricular learning skills that may enhance and promote success in school and beyond: self-regulation, collaboration, and academic mindsets. For each, the authors provide a definition, review relevant research, and give schoolbased examples of how to incorporate each skill within a classroom setting. They conclude by suggesting that practitioners and researchers pursue practices that have the potential to strengthen student engagement and acumen with non-curricular skills, including providing supportive environments, using various types of formative assessment, and employing the flipped learning model.(Sharilyn C. Steadman Chan Evans, 2013).

However, curriculum is an important part of formal education.

Another advantage in the implementation of $\mathrm{K}-13$ is the implementation of a scientific approach that is scientifically based learning activities that combine skills, knowledge and competence of learners. Teachers and students are also required to be more innovative and creative to be capability for good reasoning. The curriculum should always be dynamic (M.Hainsworth, 2017), (Fomunyam, K.g \& Teferra, 2017), in order to follow the progress and challenges of the times by always conducted change and development (Kayode, Nasirudeen, \& Al-Hasani, 2016), (Cheung, 2016). Before change and development is carried out needs to be evaluated in advance to directed and systematic (Arafeh, 2016).

However, development of the Curriculum is a very important problem, because the curriculum should always be adapted to the demands of the times. This is driven by several international studies on the ability of Indonesian students in the international arena. The results of the survey PISA 2012 shown that only 5 percent of Indonesian students are able to work on a reasoning problem high categorized; whereas Korean learners can reach 71 percent. In contrast, 78 percent of Indonesian students can work on a low-caliber matter, while Korean students are 10 percent. Other data disclosed by the Program for International Student Assessment (PISA), the results of the study in 2009 put Indonesia ranked under the top 10, from 65 countries participating PISA (Kirwan, 2015). Almost all learners of Indonesia only master lessons up to level three, while many learners from other countries can master the lesson up to level four, five, even six, so require change and curriculum development begins with the arrangement of four elements of national standards as follows:1).Graduation Competency Standars; 2).Conten Standars; 3). Proses Standars; 4).Educational Assessment Standars (Falak, 2014).The 2013 Curriculum advocates the learners with the quality of contributing to the advancement of the lives of the society where they live, the live of the nation in political, social, economic, culture, arts, technology said hamid hasan, History Education in Curriculum 2013: A New Approach to Teaching History. 166 and others. The curriculum also aims at providing the students with the competency to contribute to the welfare of humanity (Hasan, 2013).

The result of the study of PISA influences the policy changes including the curriculum also happens to other countries (Michel, 2017), (Nakayasu, 2016), In Ireland the policy changes in the mathematics subjects were conducted driven from the results of the PISA study " In particular, through its development of the Programme for International Student Assessment (PISA) it has become a technology of government, a tool in the reform of education policy (Kirwan, 2015).

Other problems faced by the Indonesian nation are various problems involving students, such as student fights, gambling, drug abuse, drugs, plagiarism, leaks and various cheating in exams. This reason is the need for curriculum development due to some current curriculum gaps. How the implemntation K-13? The purpose of this study was to describe elementary school teachers difficulties in implementing the Curriculum 2013 in Tangerang -Banten Province Indonesia.

\section{METHODS}

The research method used is qualitative with case studi type. The participants were 622 primary teachers from elementary schools in Tangerang, Indonesia, who were purposively selected. The researchers determined the sampling by setting specific requirements. The teacher should have teaching experience at least three years. Based on the results of this research we concluded that: the first, the management process applied learning is the learning of planning activities, implementation of learning activities, and evaluation of learning activities. The second, the constraints faced by the teachers' lesson plans are still not referring to the Curriculum 2013; application of learning with a scientific approach by the teacher is not optimal; teachers less than optimal in applying the learning model; and teachers are not optimal assess student learning outcomes that cover three domains of learning, namely the attitude, knowledge and skills. And the third, alternative solutions to resolve the 
problems faced is the need to make mentoring to teachers on the implementation of Curriculum 2013 (which deals with lesson plans, scientific approach, models of learning, and assessment of student learning outcomes) and conducting lesson study club (Gunawan, 2017).

The data collected is sourced from initial research to determine the focus and formulation of the problem that will be raised in a more in-depth study. Data collection is done by interview, observation, and documentation for twelve months at primary schools in Tangerang Indonesia. Interviews were conducted with 18 teachers regarding various challenges faced in implementing curriculum 2013 at schools. Besides, observations were made in two settings, namely during the learning process in the classroom and outside the classroom. Moreover, documentation is carried out to support data obtained from interviews and observations Information related to teacher perceptions of the autentic assessment.

The supporting documents of the school curriculum 2013 and standar base regulation were also analyzed. The collected data were analyzed descriptively by being matched together and based on Miles-Huberman model of qualitative research conducted in three steps following, namely, reducing data, data display, and data verification . The data that has been cut is then presented, and conclusions are drawn.

\section{RESULTS AND DISCUSSION}

Curriculum is a plan to do a written document that includes strategies to achieve the goals or desired goal, to determine the experience or achievement that would be obtained by learners in the learning process, can take place both inside and outside the school, and all the teaching materials as well as everything that can be a source of learning both in school and out of school, to fulfill the needs of learners.

The Indonesian government has made various arrangements in the standardization system of education, as stated in the government regulation of the Republic of Indonesia Regulation No. 32 2013. Elements changes in the curriculum 2013 include: (1). Competence of graduates, (2). Subjects Position changed from previously derived from subjects into developed core competencies (3) approach, the thematic integrative in Elementary School, school subjects junior high school, Compulsory Subjects and selections subjects in senior high school, Compulsory, selection and vocational subjects in vocational school; (4). curriculum structure; (5). Learning Process with scientific approach (6) Authentic assessment.

National education standards (SNP) includes eight standard: which the outline can be described as follows (PP No. 192005 and Government Regulation No. 32 2013):
1). Competency Standards
2). Content standards
3). Process Standards
4). Teachers and Education Personnel

Standards

5). Infrastructures Standards

6). Management standards

7). Funding Standards

8). Educational Assessment standards

Researcher sort highest number of opinions both negative and positive comments about the curriculum 2013, so that researchers can determine what the focus of researchers defined in this research activity.

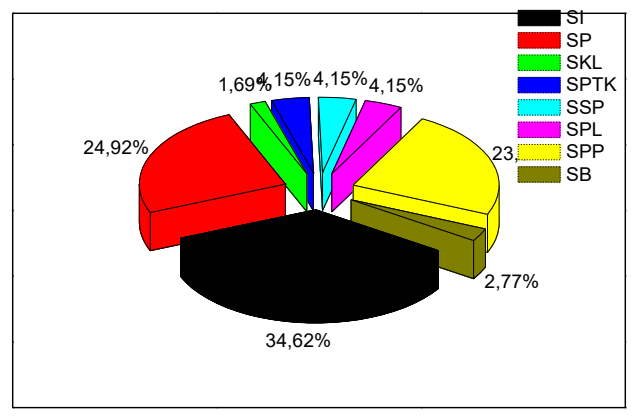

Figure 1. The result of interview about difficulties in curriculum 2013 implementation

The results of the interviews above illustrates the difficulties experienced by teachers in implementing curriculum 2013. The highest of them is the difficulty in understanding the implementation standards, the second on processes standards and third on education assessment standards.

On the Content Standards, teachers lack the understanding about the competence level that was revealed in the materials scope that are formulated based on the criteria set out in the charge compulsory provisions of the legislation, the scientific concept; and characteristics. Competence level are formulated based on the learners developmental criteria level, competence and qualifications of Indonesia; and tired competencies mastery.

In the process standard of learning, the paradigm shift from the teaching process to the learning process. The learning process in the educational unit held interactively initiative, fun, challenging, motivating the students to actively participate and provide enough space for innovation, creativity and independence in accordance with their talents, interests and students' physical and psychological development. Teachers who are used to on teacher centers should switch to the student center by using a scientific approach (Chang \& Wu, 2015),(Cápay \& Magdin, 2013).

On the assessment standards, teachers lack of understanding on authentic assessment systems and procedures. Assessment conducted in the learning process, which aims to measure the achievement of competence, progress and improvement of student learning outcomes continuously include attitudes, knowledge and skills. 
Themes used in the thematic lessons in Elementary Schools should be universal, so that in the learning process the teacher is easy to do development and make thematic whole teaching design, not very clear boundaries of subject separation but all base competency and indicators included in the theme network in with flexible taught.

\section{CONCLUSION}

The result of the study showed that in implementing the curriculum 2013 , the teachers had more difficulties the content standard $35.2 \%$, the process standard $25.3 \%$, the assessment standar $20.0 \%$, The teacher and educational personal standar $4.2 \%$, the infrastructure standard $4.2 \%$, the management standard $4.2 \%$, the graduate compotence standard $3.90 \%$, and the funding standard $3.0 \%$. The highest of them is the difficulty in understanding the implementation standard, the second on processes standards and third on assessment standards. This reseacrh is expected to lead to an outcome that will answer the needs of the community that the curriculum 2013 requires a lot of improvements and development so that all the problems found can be solved.

The first implication of this research was making a map of material characteristics to make it easier for teachers in organizing the material that has similar characteristics from each of the basic competencies that will be integrated into a theme. Since in learning process, the characteristics of each subject it should not appear clear, and there was no respite when the subject changes. The second implication showed that the socialization of the scientific approach must be more in-depth and broader in understanding the stages, not just fixing on an additional activity of students. For instance, observation activities could be conduct not only through visual but also through the process of watching, monitoring, scrutiny, examination, inspection, viewing survey, attention, reviews, and so fort.

The third implication was teacher should making authentic assessment with adjustments between core competencies and the kind of material scope, for instance, religious core competencies in science and mathemathic subject are indirectly, but the values are taken directly in religious subject.

\section{REFERENCES}

Arafeh, S. (2016). Curriculum mapping in higher education: a case study and proposed content scope and sequence mapping tool. Journal of Further and Higher Education, 40(5), 585-611. https://doi.org/10.1080/0309877X.2014.1000278

Cápay, M., \& Magdin, M. (2013). Tasks for Teaching Scientific Approach Using the Black Box Method. 64-71.
Chang, Y., \& Wu, H. (2015). A Case Study of Increasing Vocational High School Teachers Practices in Designing Interdisciplinary Use of Scientific Inquiry in Curriculum Design. 11(1), 37-51. https://doi.org/10.12973/eurasia.2015.1304a

Cheung, C. (2016). Issues in the future development of business education in Hong Kong secondary curriculum. Cogent Education, 3(1).

Falak, S. (2014). The Changing F Curriculum From 2006 To 2013. Bdk Semarang Kemenag.

Family, N., \& Surveys, H. (1861). National Family Health Surveys; National Longitudinal Survey of Youth; Panel Study of Income Dynamics; Surveys, Sample. 213-215.

Fomunyam, K.g \& Teferra, D. (2017). Curriculum Responsiveness within the Context of Decolonisationin South African Higher Education. Perspective in Education, 35(2), 196-207.

Gunawan, I. (2017). Indonesian Curriculum 2013: Instructional Management, Obstacles Faced by Teachers in Implementation and the Way Forward. 128(Icet), 56-63. https://doi.org/10.2991/icet-17.2017.9

Hasan, S. H. (2013). History Education In Curriculum 2013: $\operatorname{XIV}(2), 163-178$.

Kayode, B. K., Nasirudeen, A. I., \& Al-Hasani, S. M. A. (2016). The Should Be Goal of Education: What should be taught? and How should it be taught? Journal of Education and Practice, 7(21), 138-143. Retrieved from https://files.eric.ed.gov/fulltext/EJ1109449.pdf

Kemendikbud RI. Press workshop: Implementasi kurikulum 2013. , Kementrian Pendidikan dan Kebudayaan Republik Indonesia (2014).

Kirwan, L. (2015). Mathematics curriculum in ireland: The influence of pisa on the development of project maths. International Electronic Journal of Elementary Education, 8(2), 317-332.

M.Hainsworth. (2017). Using web 2.0 technology to enhance the science curriculum in your school. Primary Science, 25-27.

Michel, A. (2017). The contribution of PISA to the convergence of education policies in Europe. European Journal of Education, 52(2), 206-216.

Nakayasu, C. (2016). School Curriculum in Japan. Theurriculum Journal, 27(1), 134-150.

Prihantoro, C. R. (2014). The perspective of curriculum in Indonesia on environmental education. International Journal of Research Studies in Education, 4(1), 77-83. https://doi.org/10.5861/ijrse.2014.915

Retnawati, H., Hadi, S., \& Nugraha, A. C. (2016). Vocational high school teachers' difficulties in implementing the assessment in curriculum 2013 in Yogyakarta Province of Indonesia. International Journal of Instruction, 9(1), 33-48. 
https://doi.org/10.12973/iji.2016.914a

Sharilyn C. Steadman Chan Evans. (2013). Curriculum, Instruction, and the Common Core State Standards Sharilyn C. Steadman Chan Evans. 7(2), 1-5. https://doi.org/10.3766/joci.2013.v7n2p1-5 